\title{
Response to "Letter to the Editor Regarding: Patient Preferences for Glucagon-like Peptide-1 (GLP-1) Receptor Agonist Treatment of Type 2 Diabetes Mellitus in Japan: A Discrete Choice Experiment"
}

Anne B. Brooks · Jakob Langer - Tommi Tervonen • Mads Peter Hemmingsen •

Kosei Eguchi · Elizabeth D. Bacci

Received: July 21, 2020 / Published online: August 7, 2020

(C) The Author(s) 2020

Keywords: GLP-1 receptor agonist; Patient preference study; Treatment; Type 2 diabetes

\section{Dear Editor,}

We would like to thank you for the opportunity to respond to the issues raised in the letter related to our publication [1] and to provide details of the methodology to address the concerns. In the letter, the author noted concerns about the cardiovascular (CV) outcome risk reduction value used for the semaglutide $0.50 \mathrm{mg}$ profile. The author also requested

Digital Features To view digital features for this article go to https://doi.org/10.6084/m9.figshare.12728447.

A. B. Brooks

Patient-Centered Research, Evidera, Bethesda, MD, USA

J. Langer

Market Access \& External Affairs, Novo Nordisk

Pharma Ltd., Tokyo, Japan

T. Tervonen

Patient-Centered Research, Evidera, London, UK

T. Tervonen

Department of Epidemiology, University Medical Center Groningen, University of Groningen,

Groningen, The Netherlands clarification and disclosure of the references related to attribute levels.

The author is correct that the CV outcome risk reduction for the semaglutide $0.50 \mathrm{mg}$ profile (26\% versus placebo) was based on combined data for the 0.50 and $1.0 \mathrm{mg}$ doses reported in the primary publication of SUSTAIN-6 by Marso et al. [2]. This was in accordance with the primary outcome of the study and to support noninferiority and superiority testing. As presented in the appendix of Marso et al., and noted in the letter, CV risk reduction was not significant for either dose independently $(23 \%[p=0.13]$ for semaglutide $0.50 \mathrm{mg}$ and $29 \%$ [ $p=0.06$ ] for semaglutide $1.0 \mathrm{mg}$ ) [2], which was expected because the study was not powered or intended to assess the doses separately.

\section{Peter Hemmingsen}

External Valuation, Novo Nordisk A/S, Søborg, Denmark

K. Eguchi

Medical Affairs, Novo Nordisk Pharma Ltd., Tokyo, Japan

E. D. Bacci $(\bowtie)$

Patient-Centered Research, Evidera, Seattle, WA, USA

e-mail: elizabeth.bacci@evidera.com 
Table 1 Attributes, levels, and sources for the discrete choice experiment

\begin{tabular}{|c|c|c|c|}
\hline Attribute & Level & Represents & Reference \\
\hline \multirow[t]{2}{*}{$\begin{array}{l}\text { Method of } \\
\text { administration }\end{array}$} & $\begin{array}{l}\text { Multi-dose prefilled pen, used with disposable injection } \\
\text { needles, with dose adjustment possible }\end{array}$ & $\begin{array}{l}\text { Semaglutide } \\
0.50 \mathrm{mg}\end{array}$ & $\begin{array}{l}\text { Ozempic }^{\circledR} \text { prescribing } \\
\text { information at the time of } \\
\text { study conduct }\end{array}$ \\
\hline & $\begin{array}{l}\text { Single-dose, disposable prefilled pen, with no dose } \\
\text { adjustment possible }\end{array}$ & $\begin{array}{l}\text { Dulaglutide } \\
0.75 \mathrm{mg}\end{array}$ & $\begin{array}{l}\text { Trulicity }{ }^{\circledR} \text { prescribing } \\
\text { information at the time of } \\
\text { study conduct }\end{array}$ \\
\hline \multirow[t]{3}{*}{ HbAlc change } & $\begin{array}{l}\text { On average, patients achieve a } 1.9 \% \text { reduction in } \\
\text { HbAlc level }\end{array}$ & $\begin{array}{l}\text { Semaglutide } \\
0.50 \mathrm{mg}\end{array}$ & Seino et al. [6] \\
\hline & $\begin{array}{l}\text { On average, patients achieve a } 1.6 \% \text { reduction in } \\
\text { HbAlc level }\end{array}$ & $\begin{array}{l}\text { Intermediate } \\
\text { level }\end{array}$ & Not applicable \\
\hline & $\begin{array}{l}\text { On average, patients achieve a } 1.4 \% \text { reduction in } \\
\mathrm{HbAlc} \text { level }\end{array}$ & $\begin{array}{l}\text { Dulaglutide } \\
0.75 \mathrm{mg}\end{array}$ & Miyagawa et al. [7] \\
\hline \multirow[t]{2}{*}{$\begin{array}{l}\mathrm{CV} \text { risk } \\
\text { reduction }\end{array}$} & $\begin{array}{l}26 \% \text { reduction of risk in cardiovascular diseases (heart } \\
\text { attack, stroke, death due to cardiovascular diseases) }\end{array}$ & $\begin{array}{l}\text { Semaglutide } \\
0.50 \mathrm{mg}\end{array}$ & Marso et al. [2] \\
\hline & $\begin{array}{l}\text { No data for the benefit or risk in cardiovascular diseases } \\
\text { (heart attack, stroke, death due to cardiovascular } \\
\text { diseases) }\end{array}$ & $\begin{array}{l}\text { Dulaglutide } \\
0.75 \mathrm{mg}\end{array}$ & None available \\
\hline \multirow[t]{3}{*}{ Weight change } & On average, patients have a $2.2 \mathrm{~kg}$ weight loss & $\begin{array}{l}\text { Semaglutide } \\
0.50 \mathrm{mg}\end{array}$ & Seino et al. [6] \\
\hline & On average, patients have a $1.1 \mathrm{~kg}$ weight loss & $\begin{array}{l}\text { Intermediate } \\
\text { level }\end{array}$ & Not applicable \\
\hline & On average, patients do not have any weight loss & $\begin{array}{l}\text { Dulaglutide } \\
0.75 \mathrm{mg}\end{array}$ & Miyagawa et al. [7] \\
\hline \multirow[t]{3}{*}{$\begin{array}{l}\text { Common side } \\
\text { effects }\end{array}$} & $\begin{array}{l}\text { On average, } 1 \text { out of } 9 \text { patients will experience transient } \\
\text { nausea }\end{array}$ & $\begin{array}{l}\text { Semaglutide } \\
0.50 \mathrm{mg}\end{array}$ & Seino et al. [6] \\
\hline & $\begin{array}{l}\text { On average, } 1 \text { out of } 12 \text { patients will experience } \\
\text { transient nausea }\end{array}$ & $\begin{array}{l}\text { Intermediate } \\
\text { level }\end{array}$ & Not applicable \\
\hline & $\begin{array}{l}\text { On average, } 1 \text { out of } 19 \text { patients will experience } \\
\text { transient nausea }\end{array}$ & $\begin{array}{c}\text { Dulaglutide } \\
0.75 \mathrm{mg}\end{array}$ & Miyagawa et al. [7] \\
\hline
\end{tabular}

By contrast, providing the uncertainty $(95 \%$ confidence intervals) around the predicted choice probability for the semaglutide $0.50 \mathrm{mg}$ profile versus the dulaglutide $0.75 \mathrm{mg}$ profile would have strengthened our conclusions and might have alleviated the author's concern. Uncertainty around estimates from patient preference studies should be provided to help interpret results and inform patient-centered benefit-risk assessments [3]. The confidence interval around the predicted choice probability was small $(78 \%[95 \%$ confidence interval, $74-82 \%])$, supporting the conclusion that the large majority of participants preferred the semaglutide $0.50 \mathrm{mg}$ profile. 
To address the concern of the author about using a $26 \% \mathrm{CV}$ risk reduction for the semaglutide $0.50 \mathrm{mg}$ profile, we conducted an additional sensitivity analysis for the predicted choice probability. Using a $23 \% \mathrm{CV}$ risk reduction, the predicted choice probability was $76 \%$ (95\% confidence interval, $71-80 \%$ ) in favor of the semaglutide $0.50 \mathrm{mg}$ profile, which is close to the original value and supports the robustness and validity of our original conclusion.

Additional relevant data have been published since the discrete choice experiment was performed. SUSTAIN-7, a head-to-head randomized clinical trial, showed that hemoglobin A1c (HbA1c) and body weight were reduced significantly more with semaglutide $0.50 \mathrm{mg}$ than with dulaglutide $0.75 \mathrm{mg}$ [4]. This was confirmed in a network meta-analysis among patients with type 2 diabetes mellitus in Japan [5]. The REWIND study showed that dulaglutide $1.5 \mathrm{mg}$ reduces cardiovascular risk compared to placebo, although this dosage is still not currently approved in Japan.

Finally, to address the request for clarification and disclosure of the references related to attribute levels, we provide them as Table 1.

Respectfully,

Anne Brooks, BS

Jakob Langer, MS

Tommi Tervonen, PhD

Mads Peter Hemmingsen, MD

Kosei Eguchi, MD, PhD

Elizabeth Dansie Bacci, PhD

\section{ACKNOWLEDGEMENTS}

Funding. Novo Nordisk Pharma Ltd. provided the funding for this study and the journal's Rapid Service Fee. Evidera received funding from Novo Nordisk Pharma Ltd. to participate in the study and develop this letter. All authors had full access to all of the data in this study and take complete responsibility for the integrity of the data and accuracy of the data analysis. No Rapid Service Fee was received by the journal for the publication of this article.
Medical Writing Assistance. The authors would like to thank Philip Leventhal, PhD at Evidera for his assistance preparing this letter, which was funded by Novo Nordisk.

Authorship. All named authors meet the International Committee of Medical Journal Editors (ICMJE) criteria for authorship for this article, take responsibility for the integrity of the work as a whole, and have given their approval for this version to be published.

Disclosures. Jakob Langer is employed by Novo Nordisk Pharma Ltd. Mads Peter Hemmingsen is employed by Novo Nordisk A/S. Kosei Eguchi is employed by Novo Nordisk Pharma Ltd. Anne Brooks is employed by Evidera, which provides consulting and other research services to pharmaceutical, medical device, and related organizations. In this salaried position, Anne Brooks works with a variety of companies and organizations and is precluded from receiving payment or honoraria directly from these organizations for services rendered. Tommi Tervonen is employed by Evidera, which provides consulting and other research services to pharmaceutical, medical device, and related organizations. In this salaried position, Tommi Tervonen works with a variety of companies and organizations, and is precluded from receiving payment or honoraria directly from these organizations for services rendered. Elizabeth Dansie Bacci is employed by Evidera, which provides consulting and other research services to pharmaceutical, medical device, and related organizations. In this salaried position, Elizabeth Dansie Bacci works with a variety of companies and organizations and is precluded from receiving payment or honoraria directly from these organizations for services rendered.

Compliance with Ethics Guidelines. This article is based on previously conducted studies and does not contain any studies with human participants or animals performed by any of the authors.

Peer Review. Please note, contrary to the journal's standard single-blind peer review 
process, as a letter this article underwent review by a member of the journal's editorial board.

Open Access. This article is licensed under a Creative Commons Attribution-NonCommercial 4.0 International License, which permits any non-commercial use, sharing, adaptation, distribution and reproduction in any medium or format, as long as you give appropriate credit to the original author(s) and the source, provide a link to the Creative Commons licence, and indicate if changes were made. The images or other third party material in this article are included in the article's Creative Commons licence, unless indicated otherwise in a credit line to the material. If material is not included in the article's Creative Commons licence and your intended use is not permitted by statutory regulation or exceeds the permitted use, you will need to obtain permission directly from the copyright holder. To view a copy of this licence, visit http://creativecommons.org/licenses/by$\mathrm{nc} / 4.0 /$.

\section{REFERENCES}

1. Brooks A, Langer J, Tervonen T, Hemmingsen MP, Eguchi K, Bacci ED. Patient preferences for GLP-1 receptor agonist treatment of type 2 diabetes mellitus in japan: a discrete choice experiment. Diabetes Ther. 2019;10:735-49. https://doi.org/10.1007/s13300-0190591-9.
2. Marso SP, Bain SC, Consoli A, et al. Semaglutide and cardiovascular outcomes in patients with type 2 diabetes. N Engl J Med. 2016;375:1834-44. https://doi. org/10.1056/NEJMoa1607141.

3. Mott DJ, Chami N, Tervonen T. Reporting quality of marginal rates of substitution in discrete choice experiments that elicit patient preferences. Value Health. 2020. https://doi.org/10.1016/j.jval.2020.04. 1831.

4. Pratley RE, Aroda VR, Lingvay I, et al. Semaglutide versus dulaglutide once weekly in patients with type 2 diabetes (SUSTAIN 7): a randomised, openlabel, phase $3 \mathrm{~b}$ trial. Lancet Diabetes Endocrinol. 2018;6:275-86. https://doi.org/10.1016/S22138587(18)30024-X.

5. Webb N, Orme M, Witkowski M, Nakanishi R, Langer J. A network meta-analysis comparing semaglutide once-weekly with other GLP-1 receptor agonists in Japanese patients with type 2 diabetes. Diabetes Ther. 2018;9:973-86. https://doi.org/10.1007/s13300-0180397-1.

6. Seino Y, Terauchi Y, Osonoi T, et al. Safety and efficacy of semaglutide once weekly vs sitagliptin once daily, both as monotherapy in Japanese people with type 2 diabetes. Diabetes Obes Metab. 2018;20: 378-88. https://doi.org/10.1111/dom.13082.

7. Miyagawa J, Odawara M, Takamura T, Iwamoto $\mathrm{N}$, Takita Y, Imaoka T. Once-weekly glucagon-like peptide-1 receptor agonist dulaglutide is non-inferior to once-daily liraglutide and superior to placebo in Japanese patients with type 2 diabetes: a 26-week randomized phase III study. Diabetes Obes Metab. 2015;17:974-83. https://doi.org/10.1111/dom.12534. 